\title{
Graiurile poloneze din Poiana Micului şi Bulai (Bucovina de Sud) - o perspectivă sociolingvistică de tip comparativ pe baza ALAB
}

\author{
The Polish dialects from Poiana Micului and Bulai \\ (South Bukowina) - a sociolinguistic comparative \\ perspective based on ALAB
}

\author{
Florin-Teodor Olariu \\ Academia Română, Institutul de Filologie Română „A. Philippide”, Iași \\ olariuft@yahoo.com \\ Veronica Olariu \\ Academia Română, Institutul de Filologie Română „A. Philippide”, Iași \\ veronica_olariu@yahoo.com
}

\begin{abstract}
The Polish communities from Bukovina have been studied in the last period through several research projects, initiated by both Polish and Romanian researchers. One of them is the Audiovisual Linguistic Atlas of Bukovina (ALAB), which aims to realize a radiography in multimedia format of the ethnolinguistic diversity of Bukovina. Regarding the Polish ethnic minority, in 2016 two field studies have been carried out in two localities: Bulai and Poiana Micului. Following the analysis of the material thus obtained, we managed to capture some characteristics both at the linguistic and the sociolinguistic level that individualize the two communities. Thus, from a linguistic point of view, the two dialects are different both at phonetic and lexical level, the Bulai dialect being more similar to the Polish literary language. At the sociolinguistic level has been observed the presence of a strong epilinguistic component in the Polish people speech, based on the representations and the attitudes that the Polish ethnic groups have regarding the status and the vitality of their own dialects.
\end{abstract}

Keywords: Bukovina, Poles, language contact, ethnolinguistic vitality, language attitudes 


\section{SCURT EXCURS ISTORIC}

Dinamica geopolitică de la sfârşitul secolului al XVIII-lea ce a caracterizat zona de nord-vest a Moldovei istorice, aflată la confluenţa Imperiilor otoman, austroungar şi rus, a avut drept rezultat transformarea acestui spaţiu într-un adevărat mozaic etnice. Strategiile politice prin intermediul cărora Imperiul austro-ungar a modelat timp de aproape un secol şi jumătate (1774-1918) componenta demografică a părţii de nord-vest a Moldovei, redenumită ulterior Bucovina, au făcut ca pe acest teritoriu relativ restrâns ca suprafaţă (aprox. $10.000 \mathrm{~km}^{2}$ ) să convieţuiască mai multe grupuri etnice, alături de români, ca populaţie majoritară, fiind prezente în zonă atât minorităţi istorice, precum armenii, evreii sau ruşii lipoveni, cât şi grupuri etnice care au ajuns în acest areal geografic în special după crearea Bucovinei, precum germanii, ucrainenii, maghiarii sau polonezii. În mod firesc, această coabitare interetnică a unor populaţii având diferite origini lingvistice (romanice, slave şi germanice) a favorizat apariţia unui spaţiu propice fenomenelor de contact cultural, în general, şi lingvistic, în special.

Polonezii, ca grup etnic asupra căruia ne vom focaliza în studiul de faţă, au ajuns în zona Bucovinei în mod organizat începând cu sfârşitul secolului al XVIII-lea, atât ca urmare a unui context extern, dat de dorinţa autorităților austro-ungare de a creşte, prin colonizare, demografia teritoriului proaspăt anexat, cât şi a unei motivaţii interne, de factură economică, reprezentată de necesitatea căutării unor condiţii mai bune de viaţă în comparaţie cu cele din ţara de origine ${ }^{1}$.

Istoriografia referitoare la prezenţa comunităţilor poloneze în spaţiul bucovinean confirmă existenţa a trei valuri prin care etnicii polonezi s-au aşezat în Bucovina de Sud. Primii veniţi în această zonă au fost membrii celor 20 de familii de mineri care, în 1791-1792, au ajuns în Cacica din Bochnia şi, probabil, din Wieliczka (Hrenciuc, 2000, p. 440), două aşezări situate în sudul actualei Polonii, cu o bogată şi veche tradiţie a exploatării sării, aici aflându-se unele dintre cele mai vechi mine de sare din Europa, construite încă din secolul al XIII-lea. Minerii polonezi aveau rolul de

\footnotetext{
${ }^{1}$ Această motivaţie economică este şi acum prezentă în memoria colectivă a etnicilor polonezi din Suceava, fapt confirmat într-un interviu realizat în 2016 cu Maria Stanisława Mecek din Bulai (Moara), născută în 1928, în care aceasta ne declara:

- Din ce ştii matale, cum a luat naştere satul acesta?

- Aici au venit din Polonia mulţi. Aici au venit polonezii, şi români puţini erau - ici, colo, aşa. Polonezii au venit din Polonia - părinţii mei din Polonia au venit! Aici au cumpărat, au investit şi... erau mai mulţi polonezi - rar unde era câte un ortodox, român [...]. Când au venit, aşa, spuneau bunicii, aici erau numai pământuri, nu era, aşa... Ei au cumpărat de la cine era - erau nişte boieri, aşa - şi au făcut locuinţe, case... Că aici pământul e bun! Pământul e roditor! Şi în Polonia era pământ tare slab! Şi munceau oamenii... Şi acolo aveau bunici mei, de pe mama şi de pe tata, au avut acolo şi păduri, erau bine înstăriţi... Dar dacă munceau şi [aveau] puţină recoltă!! Şi au obţinut aici - aici nu era România, aici era Austria, Austro-Ungaria era aici! Şi ei au venit aici, că aici erau pământuri bune...
} 
a contribui la dezvoltarea activităţilor de extragere a sării din această zonă $\breve{2}^{2}$ unde, cu câţiva ani mai înainte (1785) se instalaseră deja ,primele 9 familii de ruteni specialişti în minerit şi evaporarea sării” (Petraru, 1995-1996, p. 358).

Cel de-al doilea val al deplasării polonezilor în Bucovina de Sud s-a desfășurat între anii '30-' 40 ai secolului al XIX-lea, fiind vorba de o colonizare pe care putem să o numim „de rang secund”. Punctul de pornire al acestei noi mobilităţi demografice este reprezentat de plecarea, în jurul anului 1803, a "muntenilor czadca" (numiţi şi kisucani / kisuţani ${ }^{3}$ ) de la graniţa polono-slovacă (ţinutul Czadca) către Bucovina de Nord, mai precis ,în trei parohii importante: Caliceanca (o suburbie a Cernăuţiului), Stara-Huta, Tereblecea, Hliboca şi Siret" (Pintescu \& Hrenciuc, 2002, p. 40-41). Ca urmare a faptului că deja după două decenii de la sosirea lor în aceste locuri se resimţea în mod acut nevoia de noi terenuri necesare unei comunităţi aflate în expansiune, reprezentanţii acesteia formulează o cerere către autorităţile vremii prin care solicitau alocarea de noi suprafeţe agricole. Acesta este contextul în care o parte dintre polonezii din cele trei parohii se vor stabili în localităţi precum Soloneţu Nou (1834), unde ajung 30 de familii din Hliboca, Pleşa (1835/1836), unde se stabilesc 24 de familii din Tereblecea şi Caliceanca, şi, în sfârşit, Poiana Micului (1942), localitate în care se vor muta 40 de familii din Stara-Huta, Crasna şi Tereblecea (Pintescu \& Hrenciuc, 2002, p. 41-46). Menţionăm că în Poiana Micului se stabilise cu patru ani înaintea venirii polonezilor (1838) o importantă comunitate de germani, care, datorită pădurilor de fagi ce înconjurau zona, numiseră localitatea Buchenheim. După venirea în 1842 a coloniştilor polonezi, această localitate devine jumătate germană, jumătate poloneză (Petraru, 1995-1996, p. 363) ${ }^{4}$.

În sfârşit, cel de-al treilea şi ultim val mai important de polonezi stabiliţi în Bucovina de Sud îşi are originea în zonele Kolbuszowa şi Ropczyce, din regiunea Rzeszów, aflată în sud-estul actualei Polonii. Aceşti colonişti au ajuns în zona bucovineană în a doua jumătate a secolului al XIX-lea şi s-au aşezat în localităţi precum Bulai, Ruda/Vicşani şi Mihoveni (Petraru, 1995-1996, p. 363) ${ }^{5}$.

\footnotetext{
${ }^{2}$ Importanţa sării în economia zonei este confirmată şi de oiconime precum Soloneţ sau Solca, ce îşi au originea în vsl. sol' 'sare'.

${ }^{3}$ „Kisuţani - nume dat imigranţilor din ţinuturile Czadeck, după numele râului Kisu[ca] ce curge la graniţa cu Slovacia" (Petraru, 1995-1996, p. 361, nota 28).

${ }^{4}$ După plecarea masivă a germanilor în anul 1940, locul acestora a fost preluat, cu timpul, de români.

${ }^{5}$ A se vedea şi informaţiile aflate pe site-ul Uniunii Poloneze din România, la adresa electronică https://dompolski.ro/orase-poloneze/bulai-2/ (consultată la 21.02.2020). În plus, provenienţa din zona Kolbuszowa a polonezilor din Bulai a fost recent reconfirmată inclusiv printr-un element de cultură gastronomică, şi anume prezența în bucătăria acestora a preparatului denumit „kapusta ziemniacanna”, în legătură cu care s-a constatat că ,atât denumirea, cât și mâncarea sunt tipice numai pentru o singură regiune din Puszcza Sandomierska [codrii din regiunea Sandomierz], pentru zona Kolbuszowa" (apud Stempel-Gancarczyk, 2020).
} 


\section{CERCETĂRI RECENTE DE TEREN: ATLASUL LINGVISTIC AUDIOVIZUAL AL BUCOVINEI (ALAB)}

În legătură cu situația actuală a comunităților poloneze din Bucovina, au existat în ultima perioadă (în special, după anul 2010) proiecte de cercetare inițiate atât de echipe de specialiști din Polonia, cât și din România care s-au focalizat pe reliefarea principalelor caracteristici la nivel sociolingvistic și etnocultural ale acestor grupuri etnice minoritare, aflate la ora actuală pe teritoriul a două state: România și Ucraina.

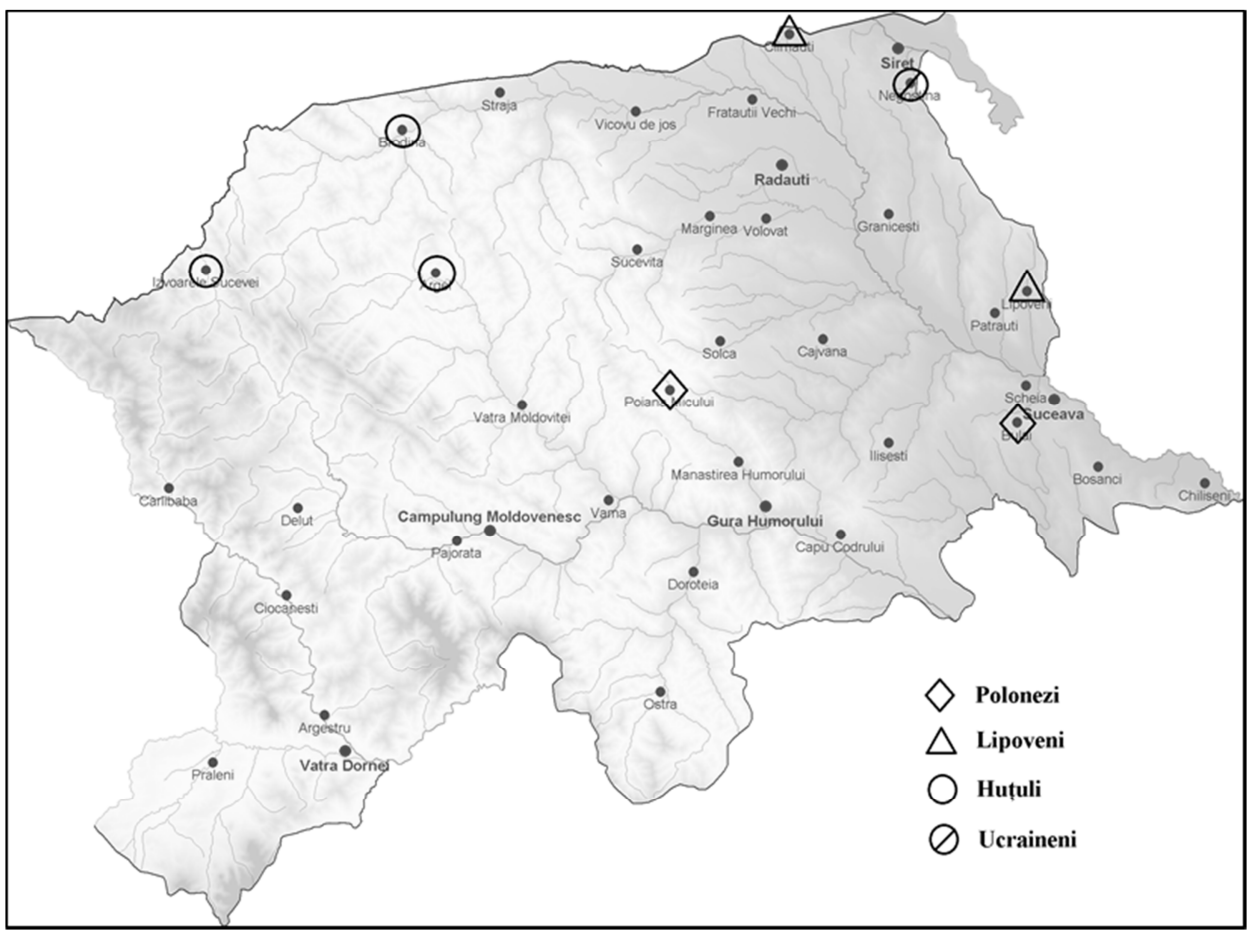

Fig. 1. Rețeaua de puncte reprezentând minorităţile etnice din ALAB

Pentru cercetătorii români ${ }^{6}$, contextul ştiinţific în care au fost întreprinse anchete în comunităţile poloneze din Bucovina de Sud a fost oferit de proiectul intitulat

\footnotetext{
${ }^{6}$ Pentru partea poloneză, menționăm în acest context proiectul intitulat Limba polonă în Bucovina Carpatică. Documentarea unui patrimoniu național pe cale de dispariție [Mowa polska na Bukowinie Karpackiej. Dokumentacja zanikającego dziedzictwa narodowego], realizat de o echipă mixtă polonoucraineană în perioada 2015-2018, precum şi cercetările derulate de Karina Stempel-Gancarczyk în cadrul unei teze de doctorat cu titlul Procesele de dispariție a limbii pe baza cercetării graiurilor
} 
Atlasul lingvistic audiovizual al Bucovinei (ALAB - http://www.philippide.ro/alab/), un proiect-pilot de geolingvistică românească care şi-a propus să realizeze o radiografie în format multimedia a spaţiului lingvistic bucovinean, prin cercetări de teren derulate atât în rândul populaţiei majoritare, cât şi al unor comunităţi etnice minoritare din zonă. În perioada 2012-2017 au fost efectuate anchete dialectale în 18 localităţi din judeţul Suceava (până la ora actuală materialul dialectal fiind încărcat pe site-ul proiectului doar pentru 10 dintre acestea), între care se află şi patru comunităţi minoritare: Poiana Micului (2016) şi Bulai (2016), reprezentând comunitatea poloneză, respectiv Brodina (2013) şi Izvoarele Sucevei (2017), localităţi reprezentative pentru comunitatea huţulă din Bucovina de Sud.

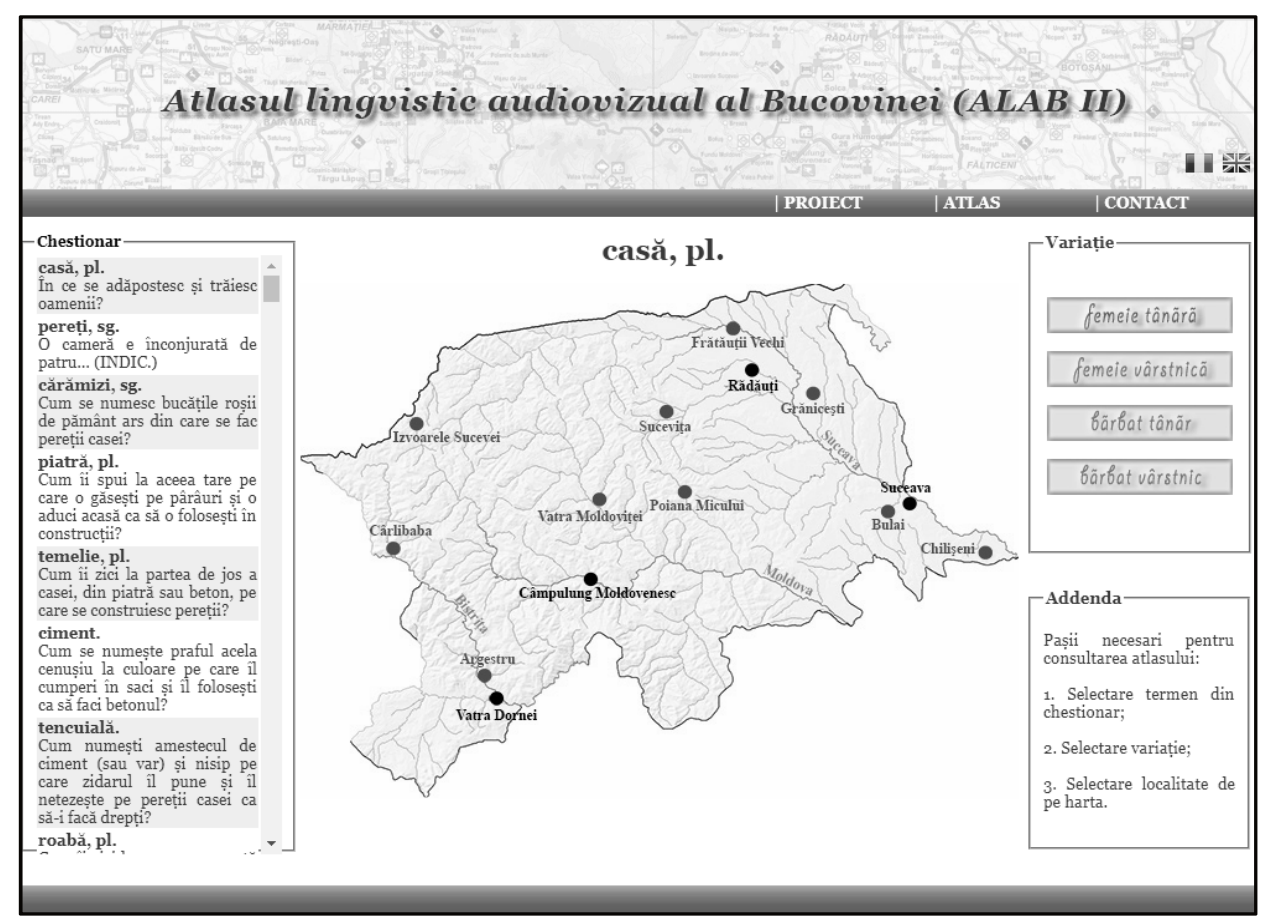

Fig. 2. Documentarea variaţiei sociolingvistice în ALAB

În ceea ce privește metodologia anchetelor dialectale, acestea au fost realizate folosindu-se atât chestionarul dialectal, format din 156 de întrebări referitoare la universul domestic cotidian (casa, agricultura, creştera animalelor etc.), cât şi prin înregistrarea de etnotexte orale, având ca principale teme de interes fie sărbătorile

poloneze din Bucovina românească [Procesy zanikania języka na podstawie badań gwar polskich na Bukowinie rumuńskiej] și susținută în anul 2019 la Varșovia (Stempel-Gancarczyk, 2020). 
calendaristice (Sărbătorile de iarnă, Sărbătorile pascale), fie cele din ciclul familial (nunta). Materialul dialectal polonez a fost obţinut în urma aplicării chestionarului, fiecare subiect bilingv anchetat fiind rugat să dea răspunsul la întrebările adresate atât în limba română, cât şi în limba maternă.

Aceste cercetări de teren ne-au oferit posibilitatea să observăm, în primul rând, unele elemente referitoare la bilingvismul ce caracterizează comunităţile studiate, dar şi aspecte ce ţin de comportamentul şi de atitudinile lingvistice pe care grupurile de etnici minoritari le manifestă în raport cu grupul majoritar, reprezentat de populaţia românească din zonă. Demersul a fost posibil graţie principiilor geolingvisticii pluridimensionale, în conformitate cu care în fiecare localitate au fost intervievate câte patru persoane, pentru a acoperi, astfel, două tipuri de variaţie cu relevanţă pentru analiza (socio)lingvistică: variaţia diageneraţională (două persoane tinere vs. două persoane în vârstă) şi variaţia diasexuală (două femei vs. doi bărbaţi) (v. Olariu, Olariu, Clim \& Luca, 2016; Olariu, Olariu \& Luca, 2016).

Această strategie euristică ne-a permis să decelăm in situ mai multe elemente reprezentative pentru dinamica sociolingvistică a comunităţilor anchetate, dintre care amintim nivelul contactului lingvistic, raportul grai vs. limbă literară, raportul limbă minoritară vs. limbă majoritară, nivelul imaginarului lingvistic (reprezentări, atitudini și motivații sociolingvistice) etc., toate aceste aspecte reprezentând parametri importanți în cartografierea traiectoriilor identitare ale comunităţilor etnice ce se dezvoltă în context minoritar.

Punctele de interes pentru cercetarea de faţă sunt reprezentate, pe de o parte, de documentarea diferenţelor lingvistice existente între cele două comunităti în care au fost realizate anchete de teren (Poiana Micului şi Bulai), şi, pe de altă parte, de reliefarea unor componente ale comportamentului sociolingvistic al etnicilor polonezi din cele două localităţi în condiţiile bilingvismului cotidian în care îşi duc existenţa.

Datele necesare pentru cercetarea (în esenţă, în cheie comparativă între cele două localităţi) atât a competenţelor, cât şi a reprezentărilor, motivaţiilor şi atitudinilor etnolingvistice pe care etnicii minoritari le manifestă în practicile lingvistice cotidiene au fost extrase, în primul rând, în urma unei analize la mai multe nivele a materialului rezultat din anchetele de teren, dar şi prin documentări bibliografice întreprinse asupra temei ce face obiectul prezentei lucrări.

\section{POIANA MICULUI VS. BULAI: DIFERENȚIERI LINGVISTICE}

Existenţa diferenţelor lingvistice între comunităţile de polonezi din Bucovina de Sud a fost confirmată atât de cercetări mai vechi, cât şi de unele mai recente, care au constatat, în principal, o fizionomie aparte a graiului din Bulai (eventual a celui din Ruda/Vicşani) în comparaţie cu graiul muntenilor (górali) din zona Humor-Cacica. Astfel, în urma unor anchete întreprinse de slaviştii I. Chiţimia şi Elena Deboveanu- 
Mălăescu în vara anului 1960 în Bulai, sat care la ora respectivă înregistra un număr de 281 de etnici polonezi, autorii respectivi constatau prezenţa unor trăsături lingvistice specifice acestei localităţi atât la nivel fonetic sau morfo-sintactic, cât şi lexical sau semantic: „În lexicul polonez din Bulai se găsesc cuvinte cu sensuri deosebite de cele din alte graiuri sau din limba comună" (Chiţimia \& Deboveanu-Mălăescu, 1963, p. 169).

Această situaţie a fost reconfirmată după aproape şase decenii prin intermediul unui amplu proiect de cercetare în cadrul căruia au fost documentate, în perioada 2016-2018, graiurile poloneze din Bucovina istorică (România şi Ucraina), regiune în care numărul etnicilor polonezi se ridică la ora actuală, conform datelor obţinute în proiectul amintit, la aproximativ 5000 persoane. Una dintre concluziile acestei vaste cercetări este că ,graiul polonez bucovinean este diferenţiat”, constatare ce acoperă, practic, mai multe aspecte la nivel lingvistic: „În primul rând se poate vorbi despre o limbă polonă bucovineană care e continuarea unei limbi polone vorbite în zona graniţelor sud-estice. În al doilea rând putem deosebi graiul muntenilor bucovineni. În al treilea rând trebuie diferenţiat graiul satului Bulai cu caracteristicile dialectului din Małopolska" (Krasowska, Pokrzyńska \& Suchomłynow, 2018, p. 376) ${ }^{7}$.

O realitate similară cu situaţia prezentată mai sus am consemnat-o şi noi prin intermediul proiectului ALAB. Datele care atestă existenţa diferenţelor lingvistice între Bulai şi Poiana Micului (localitate din zona montană a Sucevei) au fost obţinute fie prin mărturia directă a subiecţilor anchetaţi cu referire la tema în cauză, fie prin analiza comparativă a materialului lingvistic propriu-zis, rezultat în urma folosirii Chestionarului.

Referitor la prima situaţie, cea mai relevantă afirmaţie în direcţia confirmării diferenţelor dialectale între localităţile amintite o constituie mărturia preşedintelui Asociaţiei Polonezilor din comuna Moara (din care face parte şi satul Bulai), Tadeus Biseada, care în 2016 ne declara:

- Teoretic, din polona pe care o ştiu şi ce am văzut în Polonia, limba vorbită la noi în Bulai este mai apropiată de limba poloneză. La Soloneţu Nou, Poiana Micului şi Pleşa, la ei diferă un pic [...]. Dacă ar fi să vă dau exemple la câteva cuvinte cum se spune la noi şi [cum se spune] la Soloneţ: în polonă, în mod normal, bat îi spui la 'bici', la Soloneţ se spune korbacz; 'ciocanul' la noi e młotek, la ei klepocz; 'dealul' la noi e brzeg, acolo e brig; 'casa' la noi e dom, la ei e chalupa; 'grajdul' la noi e stajnia, la ei e chliw; şi ar fi multe acolo... 'oglinda' la noi e lustro, acolo-i zwyrkadlo'.

\footnotetext{
${ }^{7}$ Această diversitate dialectală ce caracterizează graiurile poloneze din Bucovina de Sud a fost analizată şi clasificată încă din anii '60 ai secolului trecut de către cercetătorii Stanisław Gogolewski și Elena Deboveanu, care au delimitat în zona menţionată patru tipuri dialectale diferite: a) graiul din Cacica; b) graiul muntenilor bucovineni; c) graiul din localitatea Ruda; d) graiurile din Bulai și Mihoveni (apud Stempel-Gancarczyk, 2019, p. 241).

${ }^{8}$ Pentru acurateţea unor transcrieri, am consultat Greń \& Krasowska, 2008.
} 
Aceste diferenţe lingvistice sunt, aşadar, conştientizate în mod activ de vorbitorii celor două grupuri de graiuri şi asumate ca atare, uneori chiar în registru ludic:

- Râdeam cu cineva că dacă ştii limba de la Soloneţ, mai ştii o limbă străină! (idem).

A doua categorie de date care susţine existenţa acestor deosebiri lingvistice este reprezentată de răspunsurile obţinute la întrebările din Chestionarul ALAB de la cei opt subiecţi intervievaţi (câte patru în fiecare dintre cele două localităţi). Diferenţele între Poiana Micului şi Bulai se pot observa atât la nivel fonetic (realizarea vocalelor şi a consoanelor), cât şi la nivel lexical.

În continuare dăm câteva exemple care să ilustreze cele afirmate mai sus. Astfel, la nivel fonetic avem:

\begin{tabular}{|l|c|c|}
\hline Termen & Bocalitate & Poiana Micului \\
\hline 'fierar' & kowal $[\mathrm{fv}]^{9}$ & kowol $[\mathrm{ft}, \mathrm{fv}, \mathrm{bt}]$ \\
\hline 'coş (la casă)' & komin $[\mathrm{fv}, \mathrm{bv}]$ & kumin $[\mathrm{ft}, \mathrm{fv}, \mathrm{bt}]$ \\
\hline 'cărbune (în sobă)' & węgiel $[\mathrm{fv}]$, wegle $[\mathrm{bv}]$ & wungle $[\mathrm{ft}, \mathrm{fv}, \mathrm{bt}]$ \\
\hline 'săpun' & $m y d t o[\mathrm{fv}, \mathrm{bv}]$ & $m y d l o[\mathrm{ft}, \mathrm{fv}, \mathrm{bt}]$ \\
\hline 'cărămidă' & $\operatorname{cegła~}[\mathrm{fv}, \mathrm{bv}]$ & $\operatorname{cegla}[\mathrm{ft}, \mathrm{fv}, \mathrm{bt}, \mathrm{bv}]$ \\
\hline 'lacăt' & $k$ kodka $[\mathrm{fv}, \mathrm{bv}]$ & klodka $[\mathrm{fv}, \mathrm{bt}, \mathrm{bv}]$ \\
\hline
\end{tabular}

La nivel lexical, pe lângă variaţia onomasiologică semnalată în fragmentul de interviu pe care l-am redat mai sus, am consemnat şi alte diferenţe între cele două localităţi în urma răspunsurilor date de subiecţi la întrebările din Chestionarul ALAB, precum cele din tabelul de mai jos:

\begin{tabular}{|l|c|c|}
\hline Termen & Bocalitate & Poiana Micului \\
\hline 'tigaie' & patelnia $[\mathrm{ft}, \mathrm{fv}, \mathrm{bv}]$ & fanglia $[\mathrm{ft}, \mathrm{fv}, \mathrm{bt}, \mathrm{bv}]$ \\
\hline 'gogoşi' & packi $[\mathrm{ft}, \mathrm{fv}, \mathrm{bt}, \mathrm{bv}]$ & pampuszki $[\mathrm{ft}, \mathrm{fv}, \mathrm{bt}, \mathrm{bv}]$ \\
\hline 'sarmale' & haluszki $[\mathrm{ft}, \mathrm{fv}, \mathrm{bt}, \mathrm{bv}]$ & golumbki $[\mathrm{ft}, \mathrm{fv}, \mathrm{bt}, \mathrm{bv}]$ \\
\hline 'piftie' & studzieniec $[\mathrm{fv}, \mathrm{bv}]$ & huszpelina $[\mathrm{ft}, \mathrm{fv}, \mathrm{bt}, \mathrm{bv}]$ \\
\hline 'tăiței' & kluski $[\mathrm{fv}, \mathrm{bv}]$ & rezaniec / rezańce $[\mathrm{fv}, \mathrm{bv}]$ \\
\hline 'sertar' & szuflada $[\mathrm{fv}, \mathrm{bv}]$ & postolek $[\mathrm{ft}, \mathrm{fv}, \mathrm{bt}]$ \\
\hline 'armăsar' & ogier $[\mathrm{fv}, \mathrm{bv}]$ & harmasar $[\mathrm{ft}, \mathrm{fv}, \mathrm{bt}]$ \\
\hline 'căruţă' & fura $[\mathrm{ft}, \mathrm{fv}, \mathrm{bt}, \mathrm{bv}]$ & wóz $[\mathrm{ft}, \mathrm{fv}, \mathrm{bt}, \mathrm{bv}]$ \\
\hline
\end{tabular}

\footnotetext{
${ }^{9}$ Simbolurile folosite pentru indexarea răspunsurilor în baza de date a proiectulu ALAB sunt: [ft] 'femeie tânără'; [fv] -'femeie în vârstă’; [bt] -'bărbat tânăr'; [bv] -'bărbat în vârstă'.
} 
Deşi extrem de redus ca număr de exemple, materialul prezentat în mod comparativ în cele două tabele ne permite câteva consideraţii de ordin lingvistic:

1. Este vizibil faptul că, atât la nivel fonetic, cât şi lexical, graiul din Bulai este mult mai apropiat de limba poloneză literară decât cel vorbit în Poiana Micului.

2. Termenul «armăsar» (cu varianta dialectală harmăsar) este intrat în graiul polonezilor din Poiana Micului din limba română, situație valabilă și pentru graiurile huţule şi cele ucrainene din nordul judeţului Suceava. Acest fapt este documentat atât de materialul înregistrat în ALAB (cei doi informatori bărbaţi din Izvoarele Sucevei), cât şi de materialul înregistrat în anii ' 70 ai secolului trecut în cadrul proiectului Noul Atlas lingvistic român, pe regiuni. Moldova şi Bucovina în cele trei localităţi huţule: Brodina, Argel şi Izvoarele Sucevei (NALR. Moldova şi Bucovina, vol. III, planşa 162). Apariţia cuvântului de origine românească armăsar, ce aparţine terminologiei păstoritului în sens larg, în graiurile minorităţilor etnice din zona Bucovinei este o consecinţă a ,prezenţei foarte timpurii a păstorilor români în Carpaţii ucraineni (ca şi polonezi şi slovaci) şi integrării lor ulterioare, destul de târzii, mediului lingvistic şi etnic înconjurător preponderent" (Robciuc, 1996, p. 67; cf. Olariu \& Olariu, 2019, p. 417-418).

3. Termenul «pampuşte» pentru 'gogoşi', înregistrat în Poiana Micului, este de origine ucraineană, acesta fiind prezent atât în graiul huţulilor, cât şi în limba română dintr-un număr însemnat de localităţi din zona montană a Bucovinei, după cum o arată materialul lingvistic din NALR. Moldova şi Bucovina, vol. IV, harta 445; alţi doi termeni comuni graiurilor poloneze şi huţule documentaţi atât în anchetele pentru ALAB, cât şi în cele pentru NALR. Moldova şi Bucovina sunt stajnia, pentru 'grajd', şi fura ( $<$ germ. Fuhre), pentru 'căruţă'.

4. În sfârşit, ultimul caz pe care vrem să-l aducem în discuţie aici este cel al denumirilor referitoare la 'tigaie (cu coadă)', pentru care în cele două graiuri poloneze avem termenii patelnia (Bulai) şi fanglia (Poiana Micului), cu o prezență extrem de interesantă în zona Bucovinei. Astfel, pentru patelnia, în afara celor două atestări din ALAB (Frătăuţii Vechi - [ft] şi Suceviţa - [fv]), am găsit doar alte două atestări: prima este în NALR. Moldova şi Bucovina, în aceeaşi localitate Frătăuţii Vechi, unde avem înregistrată forma paterne (formă de [sg.]), iar a doua se află în lucrarea Glosar regional (Arvinte, Ursu \& Bordeaianu, 1961), unde avem forma patelă, înregistrată în localitatea Ostra, lângă Gura Humorului, pentru care este dată etimologia „din ucr. patélia, patélinia"; acest din urmă exemplu a fost preluat, inclusiv cu etimologia propusă de cei trei autori, şi în dicţionarul-tezaur al limbii române (DLR), unde se prezintă ca singură atestare a termenului în discuţie. 
Interesându-ne asupra etimologiei termenului patelnia în limba poloneză, am aflat că acesta provine din fr. patelle (Brückner, 1970, s.v.), caz în care presupunem că termenul în discuţie a intrat, mai întâi, din poloneză în ucraineană, pentru a ajunge, ulterior, şi în graiurile româneşti din zona Bucovinei aflate în contact cu graiurile ucrainene ${ }^{10}$.

Referitor la termenul fanglia, acesta este consemnat în NALR. Moldova şi Bucovina, vol. II, planşa 141, în şase localităţi din zona montană a Bucovinei de Sud, inclusiv în graiul matern din toate cele trei localităţi de huţuli din reţeaua de puncte a atlasului menţionat, acest ultim aspect fiind reconfirmat şi de anchetele recente din proiectul ALAB. Termenul de bază sub care fanglia a fost indexat de către autorii NALR. Moldova şi Bucovina este fandilă, cu o prezență mult mai mare în aceeaşi zonă muntoasă a spaţiului bucovinean. Ambii termeni sunt slab reprezentaţi în lucrările lexicografice româneşti, singura lucrare de acest gen unde i-am întâlnit fiind acelaşi Glosar regional menţionat mai sus, care atestă termenul fandilă inclusiv în localităţi din sudul Bucovinei, în judeţul Neamţ, şi unde în dreptul etimologiei se precizează „cf. germ. Pfanne “tigaie”".

Deşi în paragrafele de mai sus (2. - 4.) am luat în discuţie doar câteva cuvinte întâlnite în graiurile poloneze din cele două localităţi cercetate de noi în cadrul proiectului $\mathrm{ALAB}$, coroborând situaţia acestora cu alte date de teren pe care le-am avut la dispoziţie putem concluziona că Bucovina a reprezentat de-a lungul timpului prin excelenţă un spaţiu al contactului lingvistic, în care influenţele între diversele limbi şi/sau graiuri s-au manifestat constant şi, mai ales, în mod reciproc: atât dinspre limba majoritară (română) spre limbile minoritare, cât şi invers. Astfel, cele câteva cuvinte reţinute de noi cu titlu de exemplu pentru a ilustra acest proces biunivoc demonstrează cum patru limbi: româna, poloneza, ucraineana şi germana, aparţinând de trei familii lingvistice diferite, au interferat în timp la nivel lexical, fiecare dintre ele primind, dar şi furnizând termeni proprii de la/către celelalte trei idiomuri cu care a intrat în contact. Se confirmă, aşadar, încă o dată acel topos comun în studiile referitoare la spaţiul bucovinean, în care acest teritoriu a fost considerat, din punct de vedere lingvistic şi cultural, drept o „Europă în miniatură” sau o „Elveţie a Răsăritului” (Stempel-Gancarczyk, 2016, p. 156).

\section{POIANA MICULUI VS. BULAI: DIFERENȚIERI SOCIOLINGVISTICE}

Cea de-a doua parte a analizei noastre o vom dedica, aşa cum am precizat şi anterior, schiţării unei micro-radiografii de tip sociolingvistic a celor două comu-

\footnotetext{
${ }^{10}$ Intr-adevăr, toate cele trei localităţi unde au fost consemnate formele patelnie/paterne/patelă Frătăuţii Vechi, Suceviţa, Ostra - sunt aşezate în zone unde se află (sau s-au aflat) comunităţi de ucraineni, fapt ce a facilitat contactul lingvistic dintre limbile română şi ucraineană.
} 
nităţi poloneze în care în anul 2016 am efectuat cercetări de teren. La realizarea acestui obiectiv vom folosi date ce ţin, în general, de domeniul macro-sociolingvisticii, obţinute fie din documentările noastre asupra subiectului în discuţie, fie din declaraţiile înregistrate de la subiecţi în timpul anchetelor de teren.

1

Una dintre cele mai importante constatări pe care le-am realizat cu ocazia anchetelor pentru Atlasul lingvistic audiovizual al Bucovinei a fost conştientizarea de către etnicii polonezi, dincolo de deosebirile dintre graiurile celor două localităţi documentate, şi a diferenţelor existente între propriul idiom şi limba poloneză literară.

- Cum se spune la «ceaţă» în polonă?

- Mraka! ${ }^{11}$ Sau mgla ... sau mgla. Mai corect aşa: mgla ([bv] - Poiana Micului)

- In limba polonă [cum se spune pentru «perdele»]?

- Firanki! Dar se spune şi zaslony - când tragi la geam şi ai închis geamul, să nu se vadă [...]. Se spune în două feluri [...].

- E diferenţă între ele?

- Da, oleacă mai este, da; că la noi, aici, mai spunem şi firanki, dar curat, aşa, în limba polonă, se spune zaslony (idem).

Cele două declaraţii au fost obţinute de la bărbatul în vârstă din Poiana Micului, care, intrând în contact cu limba polonă literară în diverse circumstanţe, a fost în măsură să facă o comparaţie între aceasta şi propriul grai. Adverbele „corect”, şi „curat” atribuite de către informator procesului denominativ în limba polonă standard conferă acesteia, prin faptul că cei doi itemi lexicali au o evidentă conotaţie axiologică în contextul de faţă, un statut sociolingvistic supraordonat în raport cu propriul grai, fapt ce deplasează discuţia noastră de pe axa orizontală, a variaţiei diatopice (Bulai vs. Poiana Micului), pe axa verticală, a variaţiei diastratice, mai precis în domeniul diglosiei, concept ce implică o ierarhizare valorică a două idiomuri aflate în contact.

Această situaţie dezechilibrată la nivel diastratic între practicile lingvistice în propriul grai şi cele în limba polonă literară este surprinsă în alte două declaraţii ale subiecţilor din Poiana Micului:

- Ce poloneză vorbiţi aici?

- Noi vorbim limba... limba... muntenească, aşa! Noi suntem munteni din Czadca: górale czadeccy, cam aşa s-ar traduce. [...] Noi vorbim aici popular, aşa! Eu trebuie să

${ }^{11}$ Deși I. Chiţimia şi Elena Deboveanu-Mălăescu afirmau în legătură cu acest termen că reprezintă o „formă foarte rară” (Chițimia \& Deboveanu-Mălăescu, 1963, p. 177), noi l-am întâlnit la şase dintre cei opt informatori din cele două localități. 
mă străduiesc să învăţ ca să pot vorbi literar limba polonă. (soţul subiectului [ft] Poiana Micului)

- Când vin polonezi [în sat], parcă mă tem să vorbesc cu ei, ştiţi? ([ft] - Poiana Micului)

Avem consemnate în aceste mărturii două atribute ce caracterizează situaţia diglosică în care se află etnicii polonezi din Bucovina de Sud în raport cu limba poloneză standard: pe de o parte, efortul pe care aceştia îl depun în mod conştient pentru a-şi însuşi o limbă cât mai apropiată de varianta normată a limbii ţintă şi, pe de altă parte, presiunea pe care vorbitorii nativi de grai o resimt în prezenţa unor interlocutori veniţi din Polonia, care folosesc un „cod elaborat” (Basil Bernstein) al limbii poloneze ${ }^{12}$.

În sfârşit, dorim să încheiem această secţiune dedicată raportului dintre limbă literară şi grai, aşa cum transpare acesta din materialul înregistrat în anchetele ALAB, printr-o mărturie ce cumulează atât situaţiile de tip evaluativ din primele două mărturii, cât şi cele ce vizează domeniul atitudinilor şi al reprezentărilor sociolingvistice din ultimele două:

- Cum îi spui la vasul din tablă cu care scoţi apa din fântână?

- Găleată: o găleată; două găleţi ${ }^{13}$.

- Şi în polonă?

- Putnia: jedna putnia; dwie putnie. Pe polonă e worek [?], dar noi spunem putnia.

- Pe care polonă?

- Pe polonă, polonă adevărată, ştiţi? Dacă le spui de putnia, ei nu ştiu ce-nseamnă asta! Că m-am mai scăpat eu cu câteva lucruri, ştiţi? Cu ouă: eu n-am ştiut că ouă se spune pe polonă jajko, şi eu am zis wajka; şi la ei wajka e altceva, ştiţi? Şi m-am făcut de ruşine, na [râde]! Ştiţi, noi spunem wajko pentru ouă şi la ei e jajko, nie je wajko, cum spunem [noi]; dar, na, o trecut [râde]. ([ft] - Poiana Micului)

Pe lângă atributele de „,corect” şi „,curat”, limba poloneză standard este resimţită de data aceasta şi ca ,,adevărată” - evident, în raport cu graiul natal, pe care, în acelaşi context al anchetei, soţul informatoarei noastre îl consideră „mai primitiv”. În plus, apare din nou la acelaşi subiect [ft] din Poaina Micului sentimentul discon-

\footnotetext{
${ }^{12}$ Acelaşi sentiment de jenă în a vorbi propriul grai în prezenţa unor persoane venite din Polonia a fost constatat şi în proiectul coordonat de Helena Krasowska: „Foarte des graiul polonez care s-a cristalizat în procesele spontane de comunicare în Bucovina aparţine doar sferei familiale şi vecinătăţii, fiind rezervat interacţiunii în cercul propriu. Utilizatorii ei [sic!], fiind conştienţi că acesta diferă de limba polonă vorbită de cei care vin din Polonia, se simt un pic stânjeniţi când sunt rugaţi să vorbească «în felul lor»" (Krasowska, Pokrzyńska \& Suchomłynow, 2018, p. 377).

${ }^{13}$ Răspunsurile „,în tandem”, sub forma [sg.]; [pl.], obţinute la întrebările din Chestionarul ALAB se datorează metodologiei specifice cercetărilor de geografie lingvistică, în care sunt urmărite ambele forme ale constituenților grupului nominal (substantiv, adjectiv, pronume etc.).
} 
fortului diglosic provocat de necunoaşterea unor elemente ale codului lingvistic supraordonat, fapt ce poate pune interlocutorul în situaţii subvalorizante la nivel sociolingvistic. În sfârşit, putem observa cum în acest scurt paragraf apare inclusiv fenomenul denumit în sociolingvistică amestec de cod ('code mixing'), în secvenţa „la ei e jajko, nie je waiko", o situaţie firească în cazul unor vorbitori bilingvi, aşa cum sunt polonezii din Bucovina de Sud.

\section{2}

Am putut surprinde în discursul interlocutorilor noştri, pe lângă o conştientizare a diferenţelor dintre graiurile celor două localităţi sau între acestea şi limba polonă literară, şi o problematizare a raporturilor pe care propriile graiuri le au cu unele limbi cu care acestea deţin afinităţi atât de ordin genetic, cât şi geografic:

- Râdeam cu cineva că dacă ştii limba de la Soloneț, mai ştii o limbă străină: bate undeva şi cu ucraineana pe aproape, bate şi cu slovaca - se aseamănă, are şi poloneză întrînsa... Cum spun ăştia care au făcut documentare la Soloneţ - spun că asta e gwara, limba cea vorbită, dialectul specific zonei lor din care provin (Tadeus Biseada-Bulai).

- Limba asta, ca să mai adaug ceva, e mai... De exemplu, cu limba asta populară te poţi înţelege şi cu slovacii, şi cu cehii puţin... (soţul subiectului [ft] - Poiana Micului).

- De multe ori nici nu ştiu... Noi spunem la ‘tren' kolij, şi pe limba polonă îi pociag; şi câte din astea aşa sunt, care le transformăm... Kolij nu ştiu de unde, din Rusia vine, din Ucraina, nu ştiu de unde vine, dar pe polonă îi pociag. Şi fura 'căruţă', şi fura asta tot nu-i pe polonă: îi wóz pe polonă. Şi aşa că noi [spunem] fura, fura! De unde vine fura asta, de unde vine şi kolij - astea sunt nişte vorbe, nişte cuvinte care-s aduse de undeva, care s-o transformat aici. ([bv] - Bulai).

Dacă în primele două mărturii ne plasăm cu analiza în domeniul metalingvistic, ca urmare a faptului că informaţiile referitoare la asemănările între propriile graiuri şi limbile slave înrudite genetic au fost obţinute pe cale livrescă, printr-o documentare prealabilă făcută în mod individual asupra temei în discuţie, cu cea de-a treia mărturie intrăm în domeniul epilingvistic, ce se încadrează în sfera mai largă a lingvisticii populare ('folk linguistic') şi în care putem include direcţii de cercetare precum dialectologia perceptuală (Denis Preston), sau imaginarul lingvistic (AnneMarie Houdebine-Gravaud), ambele vizate de mărturia interlocutorului nostru. Prin preocupările, reprezentările şi introspecţiile sale asupra originii unor cuvinte din propriul grai, subiectul din Bulai intră în mod indirect, prin utilizarea unor contexte de genul "de multe ori nici nu ştiu”, „nu ştiu de unde vine”, ,astea sunt nişte vorbe, nişte cuvinte care-s aduse de undeva, care s-o transformat aici", în zona de evaluare a statutului propriului idiom, subliniindu-i fragilitatea sociolingvistică la momentul actual, în condiţiile unui bilingvism asimetric, aşa cum este acesta la polonezii din Bulai. Credem că această atitudine de acceptare cu o oarecare resemnare a carac- 
terului „impur” al propriului idiom ce transpare la interlocutorul nostru, în vârstă de 80 de ani, din diverşi markeri discursivi, atât verbali (,Şi aşa că noi...”), cât şi paraverbali (intonaţia) sau nonverbali (desele ezitări şi întreruperi ale fluxului frastic) este în strânsă corelaţie cu (sau poate chiar provocată de) nostalgia acelei Arcadii originare (Stempel-Gancarczyk, 2016) în care s-au născut şi au crescut reprezentanţii mai în vârstă ai actualei comunităţi de polonezi, a cărei localizare temporară se plasează în perioada interbelică şi care se caracteriza printr-o structură solidă a reţelei identitare intracomunitare, resimţită de către membrii mai în vârstă ai comunităţii ca puternic fragilizată la ora actuală.

\section{3}

Un alt punct de interes pentru analiza comportamentului sociolingvistic al etnicilor polonezi este raportul pe care aceştia îl au cu limba română, ca limbă majoritară.

În primul rând, trebuie să precizăm faptul că, în urma constatărilor făcute în timpul anchetelor, limba română vorbită de polonezii bucovineni se apropie foarte mult de varianta sa normată, fiind mai degrabă unui dialect literar (G. Ivănescu) al acesteia. Motivul care stă la baza acestei situații își are originea într-o realitate de natură sociolingvistică (încă) prezentă în comunitățile poloneze din județul Suceava, descrisă de către soţul subiectului [ft] din Poiana Micului:

- Când se naşte un copil într-o familie poloneză [...], atunci copilul învaţă limba maternă, limba polonă. Şi de-abia când merge la grădiniţă, acolo învaţă limba oficială, limba română.

Altfel spus, petrecându-şi primii ani de viaţă într-o comunitate relativ omogenă (ne referim în special la polonezii în zona Humor-Cacica), în care prima (şi, uneori, singura) limbă practicată în familie este limba maternă, contextul social în care copiii etnicilor minoritari vor lua pentru prima dată contact cu limba majoritară, şi anume grădiniţa, îşi va lăsa în mod inevitabil amprenta asupra caracteristicilor acesteia, ţinând cont în acest cadru instituțional ei vor învăța varianta literară a limbii române, destul de diferită de graiurile bucovinene din zonă.

Această realitate este reconfirmată cu fermitate de către o interlocutoare de 88 de ani din localitatea Bulai, care ne declara:

- Localităţile din jurul Bulaiului se deosebesc ca grai de cel de aici? ${ }^{14}$

- Daaa, se deosebesc, sigur că da! Mai ales Sfântul Ilie, aici, vorbersc cu $\hat{s}, f \hat{s}$, aşa, di $\hat{s} i$, de acestea, aşa! Dar la noi nu, aici se vorbeşte aşa... Şi amu, că lumea e mai civilizată, aşa, se vorbeşte mult mai frumos, pe româneşte chiar!

\footnotetext{
${ }^{14}$ În mod evident, întrebarea vizează deosebirile între graiurile româneşti din zonă.
} 
Aşadar, „coloratura” dialectală a graiurilor româneşti din împrejurimi este acut resimţită şi conştientizată de vorbitorii minoritari, însă, în acelaşi timp, şi ,,penalizată” ca atare la nivel de practici discursive. Aceeaşi situaţie a afirmării alterităţii lingvistice în raport cu grupul majoritar (aşadar, de data aceasta la nivel intercomunitar, spre deosebire de diferenţele lingvistice intracomunitare semnalate până acum) o reîntâlnim şi în următorul fragment, înregistrat cu acelaşi subiect:

- O cameră e înconjurată de patru... (INDIC.)

- 'Pereţi'.

- Şi la unul cum îi spui?

- 'Perete'.

- Aşa spui matale când vorbeşti: 'perete'?

- Da!

- Deci nu spui 'pareĉe' sau...

- Nu, nu, la noi nu se vorbeşte aşa! Asta în Sfântul Ilie, v-am spus că acolo... La noi se spune perete şi pereţi! [intonaţie emfatică pe pronunția literară a celor doi termeni]

Putem observa şi în acest fragment fermitatea cu care este respinsă orice asociere a limbii române vorbite de etnicii polonezi cu vreo variantă dialectală a acesteia, cel puţin la nivel fonetic.

Acest fapt nu înseamnă că vorbitorii polonezi nu cunosc dimensiunea dialectală a limbii române vorbite în zona Bucovinei, altfel spus, variaţia diatopică a acesteia, pe care unii dintre ei chiar o folosesc în răspunsurile date la întrebările din Chestionarul ALAB:

- In ce se transformă praful când plouă?

- În glod se transformă, în noroi.

- Cum aţi spus prima dată?

- Glod! Glod mai spun o seamă, aşa, mai spun ţiganii; dar noroi e, aşa, normal ([bv] Poiana Micului)

- Cum îi spui la aceea care prinde şoareci şi îi mânâncă?

- Mâtu' '.. Pisica: o pisică; două pisici.

- Deci matale 'pisică' îi spui în română, nu?

- Da! Pisică se spune aşa, mai curat! Se mai spunea mât... (idem)

- Ce cresc în pământ, în cuiburi, şi se folosesc la mâncare?

- Cartofi: un cartof; doi cartofi.

- Se mai spune şi altcumva?

- Barabule, dar mai țărăneşte, cum ar veni [râde]. ([ft] - Poiana Micului)

Practic, aproximativ aceleaşi calificative pe care subiectul [bv] din Poiana Micului le folosea mai sus cu referire la diferenţele dintre limba polonă literară şi graiul natal sunt reluate acum pentru a caracteriza raportul dintre limba română literară şi graiurile româneşti din zonă. Şi, la fel ca în situaţia anterioară, şi de data aceasta, 
prin utilizarea unor contexte evaluative de tipul „mai curat” vs. „mai țărăneşte”, „mai spun ţiganii”, intrăm în domeniul epilingvistic al imaginarului şi al reprezentărilor lingvistice, ce demonstrează deţinerea de către etnicii polonezi nu doar a unor competenţe idiomatice (Eugen Coşeriu) în limba română, ci şi a unor competenţe expresive, care pot fi relevante, în cele din urmă, inclusiv pentru o analiză de tip diastratic.

Deşi, aşa cum am putut observa în rândurile de mai sus, unii termeni dialectali specifici limbii române din zona în care trăiesc nu le sunt străini etnicilor polonezi din Bucovina, putem afirma, ca o concluzie, că aceştia au, totuşi, competenţe reduse la acest nivel, limba română pe care o vorbesc rămânând una destul de apropiată de varianta sa literară.

\section{4}

O discuţie aparte, însă în continuarea celei de mai sus, o presupune termenii de origine română intraţi în graiurile cercetate. Putem distinge aici două categorii: a) termeni vechi, intraţi ca urmare a contactului în diacronie între cele două idiomuri; b) termeni recenţi, cu statut neologic la nivel de grai.

\section{1}

În categoria termenilor româneşti prezenţi în graiurile poloneze din zonă ca urmare a coabitării de-a lungul timpului între cele două grupuri etnice, pe lângă (h)armăsar, despre care am discutat deja, menţionăm aici şi mamaliga, pentru care am obţinut următorul răspuns de la subiectul [fv] din Poiana Micului la întrebarea din Chestionarul ALAB:

- Ce faci din făină de porumb, când îi pui apă şi sare şi o fierbi în ceaun?

- Mamaliga: jedna mamaliga; dwe mamaliga - o mămăligă; două mamaliga [sic!] [râde]

- Deci la fel [se spune] şi în una, şi în alta...

- Da, da! Mamaliga e în limba română. Na, dar noi suntem români şi noi consumăm... cel mai mare consumator de mămăligă e românul! [râde].

Se poate observa în acest paragraf cum o cutumă comună celor două comunități aflate în contact - aceea de a consuma acelaşi produs culinar - poate declanşa, printr-o mediere de tip onomasiologic (mămăligă vs. mamaliga), o autoidentificare a etnicului minoritar cu membrii grupului majoritar, Aşadar, pornindu-se de la o cvasi-omonimie între cele două limbi, se poate ajunge la o asumare de către etnicii minoritari a identităţii supraordonate la nivel social, în speţă cea românească, printr-o echivalare/suprapunere a etniei cu cetăţenia: „noi suntem români” ${ }^{\prime 15}$, transgresându-se, astfel, diferenţele dintre cele două concepte existente la nivel teoretic.

\footnotetext{
${ }^{15}$ Această identitate duală, resimţită ca firească de către etnicii polonezi, este confirmată şi de un alt interlocutor din Poiana Micului: „Când se naşte un copil într-o familie... [ezită] poloneză, ca să zic aşa,
} 


\section{2}

A doua categorie de cuvinte româneşti prezente în graiurile poloneze din Bucovina o reprezintă cea referitoare la realităţile domestice intrate relativ recent în universul casnic al interlocutorilor noştri, deci inclusiv în limba acestora. Un exemplu relevant pentru această situaţie îl reprezintă termenul aragaz:

- Cum se spune la acela cu butelie, pe care se face mâncarea?

- Aragaz: un aragaz; două aragazuri.

- Şi în polonă?

- [ezită] Exact în polonă... noi tot spunem aragaz. Dar au fost polonezii nu de mult la noi [...] şi au spus că-i kuchenka. Dar asta-i deja a lor - noi, tot e aragaz pentru noi! ([ft] - Poiana Micului)

- Cum se spune la acela cu butelie, pe care se face mâncarea?

- Aragaz. [...] Aragaz e în limba română şi... nu ştiu pe polonă [...]. În limba polonă nu ştiu cum se spune, că noi înainte nu aveam aceea... Acuma sunt aragazuri şi aşa te-ai obişnuit şi aşa-i spui, nu? Dar în limba polonă nu ştiu! Dar eu am avut aragaz, Doamne mă iartă?!?! [râde]

Chiar dacă la ora actuală există legături puternice cu ţara-mamă, comunităţile poloneze din regiunea bucovineană au evoluat aproape două secole relativ independent faţă de aceasta din punct de vedere geopolitic, deci inclusiv lingvistic. Aşa se explică faptul că atunci când au apărut noi nevoi denominative, graiurile au apelat la împrumuturi din limba majoritară din zonă, cu care era în contact nemijlocit, şi anume din limba română. Această situaţie apare în materialul ALAB şi în cazul altor doi termeni neologici utilizaţi de etnicii polonezi şi preluaţi, la rândul lor, din limba română: drujba (< rus. Дружба, marcă comercială), folosit de informatori pentru a reda pl. piła łańcuchowa, şi blugi (< engl. blue-jeans), folosit de majoritatea interlocutorilor noştri pentru a reda pl. dżinsy.

5

Pornind de la situaţia descoperită în teren în legătură cu acest din urmă termen, vrem să evidenţiem existenţa unei alte variaţii în graiurile studiate, pe care am menţionat-o deja în prima parte a articolului, şi anume variaţia diageneraţională. Astfel, în legătură cu lexemul discutat mai sus, am semnalat prezenţa termenului dżinsy în răspunsurile subiecţilor [ft] din Bulai şi [bt] din Poiana Micului, fapt ce poate fi explicat printr-o deschidere mai mare a generaţiei tinere, fie prin intermediul

pentru că noi ne considerăm polonezi - şi români suntem, nu avem cum să nu fim români [...]" (soţul subiectului [ft]). Acea ezitare pe care informatorul a avut-o înaintea momentului de afirmare a identităţii primare relevă faptul că, la etnicii minoritari, procesul de autodefinire identitară presupune, la fiecare concretizare discursivă a sa, un laborios proces electiv, ce implică atât structurile cognitive, cât şi cele emoţionale ale acestora. 
unui proces educativ mai îndelungat, fie a unui acces mai facil la mass-media, către cultura poloneză, de unde au preluat şi denumirea respectivă, specifică limbii materne.

Un alt caz este cel al termenului fajton, utilizat ca răspuns la întrebarea pentru 'căruţă' de către interlocutoarele [ft] din Bulai şi Poiana Micului, precum şi de către [bt] din Bulai. Deşi presupunem că termenul este cvasi-cunoscut în cele două comunităţi (vezi, în acest sens, prezenţa cuvântului în discuţie în Greń \& Krasowska, 2008, p. 72), utilizarea în anchetele ALAB a acestui cuvânt de provenienţă românească doar de către reprezentanţii tineri ai comunităţilor poloneze poate fi explicat prin faptul că respectivul lexem este resimţit ca un termen neologic ${ }^{16}$, deci marcat expresiv la nivel social, fapt ce poate justifica, astfel, adoptarea lui de către tineri în propriul lor limbaj, cunoscut fiind faptul că aceștia sunt, în general, mult mai deschişi la inovaţii lingvistice. Faptul că acest termen este folosit în răspunsurile celor trei tineri interlocutori alături de $w u z$ şi, respectiv, fura, denumiri specifice celor două graiuri pentru 'căruţă', ar putea indica începutul unui proces de schimbare lingvistică, în urma căruia este posibil ca termenii „tradiţionali” să fie înlocuiţi, în timp, de termenul preluat din limba română. Răspunsul dat de [ft] din Poiana Micului face destul de plauzibil un astfel de scenariu:

- La ce înhami caii?

- La faiton; un faiton; două faitoane.

- Şi în polonă?

- Noi tot mai mult [spunem] fajton, dar şi wus: jeden wus; dwa wuse.

Această afirmaţie cu structură binară şi cu carater dihotomic: „noi tot mai mult... dar şi..." arată direcţia procesului de schimbare lingvistică, ce merge dinspre graiul natal înspre limba română.

În sfârşit, un ultim caz ce ilustrează existenţa unei variaţii diageneraţionale în graiurile analizate îl consemnăm prin intermediul răspunsurilor date de respondenţii din Poiana Micului la întrebarea referitoare la 'tăiţei': „Cum le spui la aceia făcuţi din aluat, pe care îi tai foarte subţiri şi lungi şi îi pui în supă ori în lapte?”. Răspunsurile obţinute se grupează pe două categorii: a) [fv] şi [bv], aşadar reprezentanţii generaţiei de peste 65 de ani, au răspuns cu variantele riezańec / riezańcy (vezi tabelul mai sus); b) reprezentanţii tinerei generaţii: [ft] şi [bt] au indicat

\footnotetext{
${ }^{16}$ Faiton cu sensul de 'căruță' este un cvasi-neologism inclusiv pentru limba română, afirmaţie ce poate fi demonstrată prin faptul că în Dicţionarul limbii române (DA), literele F-I, publicat în anul 1934 de către Academia Română, pentru atelajul cu patru roți era dată următoarea definiţie: „Trăsură (de lux) deschisă, cu patru roate, înaltă şi uşoară”, iar pentru a susţine această definiţie sunt date două exemple: unul din Vasile Alecsandri, şi altul din Mihai Eminescu, aşadar exemple livreşti, ce demonstrează faptul că la vremea respectivă acest cuvânt nu era încă intrat, cu acest sens, în graiuri.
} 
ca denumire proprie pentru acest produs termenul makarony. Variaţia diageneraţională în cazul de faţă poate fi o urmare directă a unui aspect ce ţine de evoluţia culturii gastronomice în zilele noastre, în sensul că doar generaţia mai în vârstă mai face în casă acest produs destul de clasic pentru bucătăria tradiţională, în timp ce tânăra generaţie este predispusă mai degrabă să cumpere din comerţ produsul respectiv, fapt ce poate justifica apariţia termenului makarony (= 'paste', deci o denumire mult mai comercială, cu statut supraordonat în raport cu 'tăiţei' ${ }^{, 17}$ ) în limbajul tinerilor interlocutori. Această supoziţie este confirmată, de altfel, de către subiectul [ft], chiar dacă într-o manieră oarecum contradictorie (,fac acasă” vs. ,avem la market”):

- Deci cum se numesc ăia?

- Tăiţei.

- Şi în poloneză?

- Noi spunem chiar makarony! Makarony fac acasă - mama mai făcea! Acum noi, gospodinele, avem la market.

\section{6}

Dacă în capitolul anterior am constatat existenţa unei variaţii diageneraţionale în cadrul răspunsurilor primite în anchetele noastre de teren, în acest ultim capitol dedicat materialului lingvistic propriu-zis din arhiva ALAB dorim să reliefăm câteva aspecte ce ţin de variaţia diamezică, definită ca diferenţă între codul scris şi codul oral al unui vorbitor. Altfel spus, dacă până în acest punct analizele noastre la nivel lingvistic s-au bazat exclusiv pe mărturiile orale ale interlocutorilor noştri, în rândurile următoare vom face câteva precizări de factură lingvistică pornind de la mărturiile scrise ale persoanelor participante la anchetele ALAB. Acest tip de analiză a fost posibil ca urmare a faptului că unul dintre obiectivele de bază ale proiectului menţionat a constat în realizarea unei arhive de documente scrise în registru dialectal, constituită, în principal, din scrisori, cărţi poştale sau alte tipuri de documente personale pe care subiecţii noştri au avut bunăvoinţa să ni le ofere ca bază documentară în cadrul Atlasului lingvistic audiovizual al Bucovinei ${ }^{18}$. Dăm în continuare o secvenţă (două pagini) dintr-o scrisoare trimisă, în anul 1978, de interlocutoarea [fv] din Bulai către fiica sa, aflată la cămin, în Bucureşti:

\footnotetext{
${ }^{17}$ Este posibil ca apariţia lui makarony în limbajul tinerilor să-şi aibă originea într-un proces metonimic, bazat pe asocierea dintre 'paste' şi 'tăiţei', pe principiul (aplicat oarecum invers!) pars pro toto. Această ipoteză este într-o oarecare măsură susţinută de afirmaţia tinerei interlocutoare ([ft]): ,pe română îs tăiţei, macaroane, fidea... mă rog, mai multe, şi la noi [...] îs makarony".

${ }^{18}$ Din această arhivă în curs de constituire, pe site-ul proiectului am publicat până la ora actuală doar patru astfel de documente, la adresa: http://www.philippide.ro/alab/scrisori.php.
} 


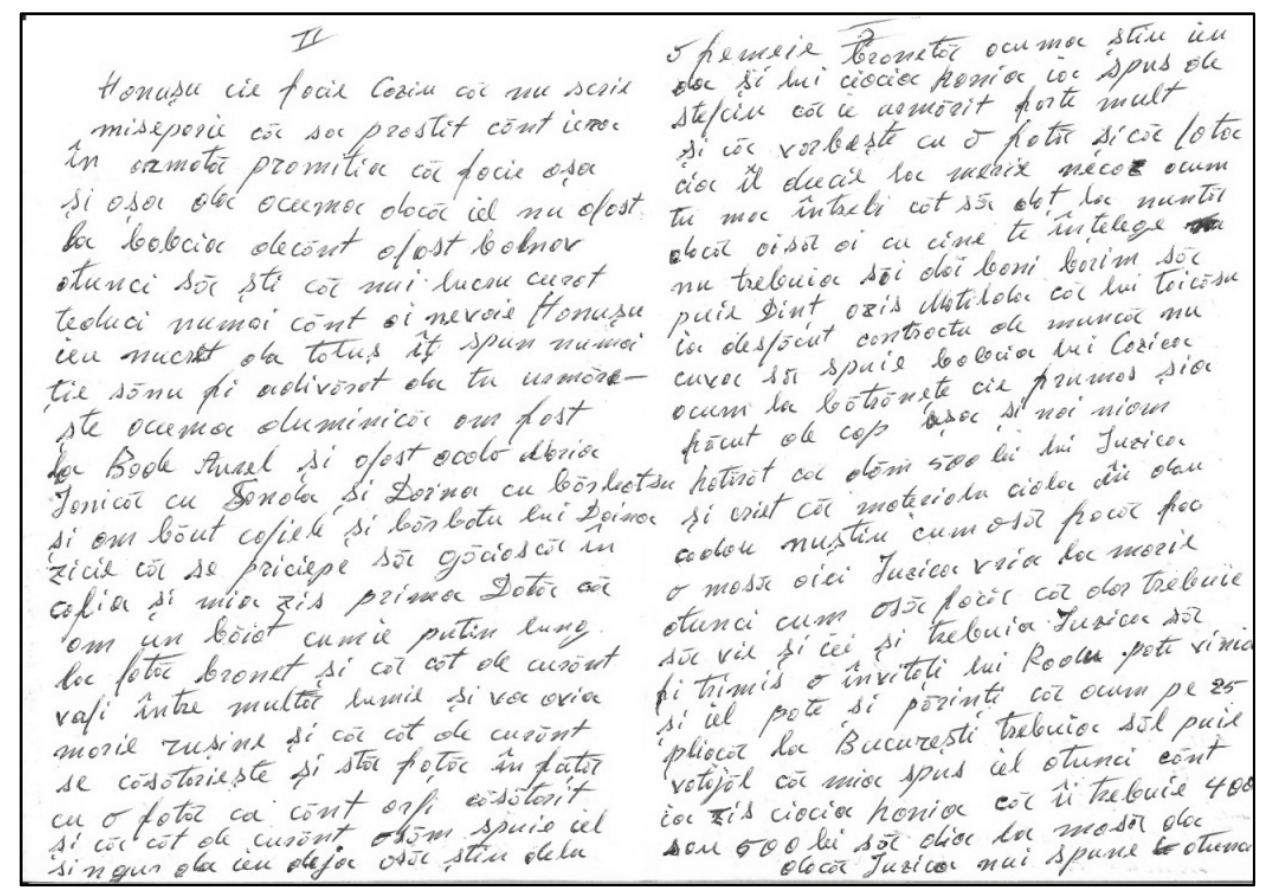

Fig. 3. Fragment de scrisoare din Bulai (1978)

În cele două pagini ale documentului prezentat mai sus pot fi observate unele aspecte şi fenomene lingvistice ce caracterizează limba română scrisă de către subiectul nostru, dintre care enumerăm:

a) prima şi cea mai evidentă caracteristică a acestui document este caracterul său de scripta continua, autoarea nefolosind semne ortografice pentru a marca vreo structură grafică a textului;

b) la acelaşi nivel al semnelor ortografice, semnalăm absenţa generală a cratimei în exemple precum: ,sa prostit" $(\approx$ s-a), ,nui lucru curat" $(\approx$ nu-i $)$, ,mia zis" $(\approx$ mi-a), ,ia spus" $(\approx \mathrm{i}-\mathrm{a})$, ,ssia făcut de cap" $(\approx$ şi-a $)$, ,noi niam hotărăt" $(\approx$ ne-am) etc.;

c) în schimb, am semnalat exemple cu scrierea împreună a mai multor cuvinte (aşadar, un fel de scripta continua la nivel micro de data aceasta): „miseparie că” ( $\approx$ mi se pare); ,decănt o fost” $(\approx$ de când); ,ieu nucret” ( $\approx$ nu cred); „nuştiu cum” ( $\approx$ nu ştiu);

d) la nivel lexical, constatăm perenitatea şi, astfel, importanţa terminologiei gradelor de rudenie în sistemul denominativ specific limbii unei comunităţi lingvistice, importanţă confirmată în cazul de faţă prin păstrarea unor astfel de termeni din propriul grai inclusiv în texte scrise în limba română: este 
vorba despre babcia şi dziadzia (acest din urmă termen consemnat în forma cu africatele asurzite: ciacia), care apar în text alături de termenul românesc bade (,Bade Aurel”);

e) cele mai numeroase fenomene lingvistice se observă la nivel fonetic, dintre care consemnăm:

1. închiderea lui $e>i$ : adivărat $(\approx$ adevărat $)$; ,pote vinia” ( $\approx$ venea $)$;

2. trecerea lui ea > ia în diftongul [ea]: promitia ( $\approx$ promitea); „şi va avia" $(\approx$ avea $) ;$,să dia la masă" $(\approx$ dea $) ;$,vria la marie" ( $\approx$ vrea $) ;$

3. diftongarea lui $e>i e$ : ,am băut cafiele" ( $\approx$ cafele); "vria la marie"

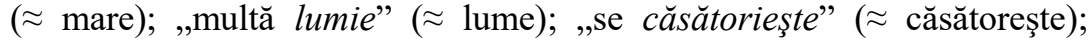
,şi criet că" ( $\approx$ cred);

4. diftongarea după africate: „,cie facie” ( $\approx$ ce face); ,zicie că” ( $\approx$ zice); ,se priciepe să” ( $\approx$ se pricepe); ,îl ducie la” ( $\approx$ duce); ,cie frumos” ( $\approx$ ce);

5. reducerea diftongului oa>o: ,,ie urmărit forte mult" ( $\approx$ foarte); ,pote vinia şi iel, pote şi părinţi[i]" ( $\approx$ poate);

6. deschiderea lui $u>o$ : „lung la faţă, bronet" ( $\approx$ brunet); „o femeie bronetă" ( $\approx$ brunetă);

7. deschiderea lui $\hat{a}>\breve{a}$ în interiorul cuvântului: „cănt iera” ( $\approx$ când); „,decănt o fost” ( $\approx$ de când); ,căt de curănt” ( $\approx$ cât de curând); ,acuma la bătrăneţe" ( $\approx$ bătrâneţe);

8. asurzirea unor consoane sonore: „cănt iera” ( $\approx$ când); ,ieu nucret” ( $\approx$ nu cred); „căt de curănt" ( $\approx$ cât de curând); ,şi criet că” ( $\approx$ cred);

9. pronunţarea dură a unor africate şi fricative: „totuş ît spun” ( $\approx$ totuşi îţi), „căt să daţ" ( $\approx$ daţi);

10. iotacizarea unor verbe la modul conjunctiv: „o săm spuie el” ( $\approx$ să-mi spună); „,barim să puie” ( $\approx$ să pună); ,trebuie să vie” ( $\approx$ să vină); „trebuia săl puie" ( $~$ să-l pună);

11. formarea viitorului cu modul conjunctiv (,viitorul popular”): „o săm spuie el” ( $\approx$ îmi va spune); ,o să ştiu de la o femeie” ( $\approx$ voi şti); „dacă $a i$ să $a i "$ ( $\approx$ vei avea), „cum o să facă” ( $\approx$ va face).

$\mathrm{O}$ primă constatare este aceea că scrierea din textul de faţă are un pronunţat caracter fonetic, în sensul că distanţa dintre codul oral şi codul scris este mult redusă, acesta din urmă preluând multe elemente din vorbire ${ }^{19}$.

$\mathrm{O}$ a doua evidenţă ţine de caracterul dialectal al limbii utilizate în redactarea textului, în special la nivel fonetic: majoritatea fenomenelor descrise mai sus sunt

\footnotetext{
${ }^{19}$ În aceste condiţii, putem spune că interlocutoarea noastră „scrie (aproape) cum vorbeşte”, fapt ce poate fi verificat printr-o analiză comparativă a limbii române folosite în textul de faţă cu cea utilizată în etnotextele înregistrate în format video cu acelaşi subiect, texte care se regăsesc pe site-ul proiectului $\mathrm{ALAB}$, la următoarea adresă electronică: http://www.philippide.ro/alab/anchete_alab.php?pg=cauta etnotext\&id_pct=31\&id_sub=15\&sex $=$ femeiesc\&varsta $=\mathrm{v} \% \mathrm{C} 3 \% \mathrm{~A} 2$ rstnic .
} 
caracteristice subdialectului moldovenesc, din care fac parte şi graiurile bucovinene cu care graiurile poloneze analizate au intrat în contact şi de unde au preluat, astfel, aceste mărci dialectale.

$\mathrm{Cu}$ toate acestea, există destul de multe aspecte atât la nivel lexical, cât şi fonetic (lipsa fricativizării africatelor, lipsa închiderii vocalelor finale etc.), care caracterizează subdialectul moldovenesc al limbii române și care nu se regăsesc în textul redat aici, fapt ce plasează limba română utilizată în redactarea textului la un nivel lingvistic intermediar, între graiurile bucovinene din zona vizată şi limba română literară - aceasta fiind cea de-a treia caracteristică a limbii române folosite în redactarea documentului analizat.

Coroborând toate aceste constatări, putem spune că în cazul de faţă suntem în prezenţa unei variaţii diamezice minimale, date de existenţa unei distanţe reduse între vorbire şi scriere, altfel spus, între concretizările codului oral şi a codului scris. Iar această realitate este una firească, în condiţiile în care limba română în comunităţile poloneze este învăţată, aşa cum am menţionat deja, de-abia în etapa şcolarizării, varianta astfel însuşită fiind cea literară, care se va modifica destul de puţin în diacronie sub influenţa graiurilor româneşti din vecinătate şi care va fi utilizată ca atare atât în scris, cât şi în vorbire.

\section{CONSIDERAȚII FINALE}

O concluzie generală pe care putem să o formulăm în urma analizelor punctuale întreprinse asupra materialului înregistrat în cele două comunități poloneze prin intermediul anchetelor ALAB este că acestea se caracterizează printr-o mare mobilitate sociolingvistică, reflectată atât la nivelul sistemului lingvistic propriu-zis (împrumuturi lexicale ca urmare a unui contact prelungit cu celelalte idiomuri din zonă), cât și la cel al practicilor, al reprezentărilor și al atitudinilor lingvistice întâlnite la etnicii polonezi cu referire la propriile graiuri sau la limbile supraordonate în raport cu acestea: limba poloneză literară, pe de o parte, și limba română, pe de altă parte. Această dinamică accentuată a unor importanți parametri identitari, cum sunt în cazul de față cei lingvistici, are, în mod inevitabil, repercusiuni inclusiv asupra vitalității și a loialității etnolingvistice aferente graiurilor analizate. În acest sens, am reperat deja o curbă descendentă în cazul celor două variabile sociolingvistice mai ales în cazul localității Bulai, ca urmare a unor factori specifici întâlniţi aici, cum ar fi o expunere geografică mai mare la centrele urbane din zonă și un declin demografic mai accentuat în interiorul comunității poloneze. Toate aceste evoluții, care își au originea în profundele schimbări sociopolitice și etnoculturale intervenite în societatea românească postbelică, au periclitat profund acel status-quo existent în perioada interbelică, ce se caracteriza prin stabilitatea structurilor identitare (lingvistice, sociale, etnoculturale) la nivel comunitar, acea stare de lucruri fiind rememorată cu 
nostalgie la ora actuală de către membrii mai în vârstă ai comunităţii poloneze din Bulai din perspectiva unui in illo tempore pierdut odată cu propria copilărie.

Studiu elaborat in cadrul proiectului PN-III-P1-1.2-PCCDI-2017-0116 (PNCDI III), finanţat de Ministerul Cercetării și Inovării din România, CCCDI-UEFISCDI.

Ținem să mulțumim în mod deosebit colegilor Tomasz Cychnerski (Poznan) şi Karina Stempel-Gancarczyk (Varşovia) pentru sprijinul științific acordat pe perioada redactării lucrării. 


\section{BIBLIOGRAFIE}

Arvinte, V., Ursu, D., Bordeaianu, M. (1961). Glosar regional. București: Editura Academiei Române. Brückner, Al. (1970). Stownik etymologiczny języka polskiego. Warszawa: Wiedza Powszechna.

Chiţimia, I., Deboveanu-Mălăescu, E. (1963). Graiul şi folclorul polonez din Bulai, raionul Suceava. In Romanoslavica. VII, pp. 159-186.

Greń, Z., Krasowska, H. (2008). Słownik górali polskich na Bukowinie. Warszawa: Slawistyczny Ośrodek Wydawniczy.

Hrenciuc, D. (2000). Minoritatea polonă din Bucovina. In Analele Bucovinei. VII/2, pp. 439-456.

Krasowska, H., Pokrzyńska, M., Suchomłynow, L.A. (2018). Świadectwo zanikajacego dziedzictwa. Mowa polska na Bukowinie: Rumunia-Ukraina. Warszawa: Instytut Slawistyki Polskiej Akademii Nauk.

Olariu, Fl.-T., Olariu, V. (2019). Identitate culturală şi comportament sociolingvistic în context minoritar: huţulii şi polonezii din Bucovina de Sud. In F. Solomon, Al.-L. Cohal \& L. Rados (ed.). Ipostaze istorice ale mişcărilor de populaţie şi modele identitare etnolingvistice actuale. Bucureşti: Editura Academiei Române, pp. 413-427.

Olariu, Fl.-T., Olariu, V., Clim, M.-R., Luca, R. (2016). La cartographie linguistique roumaine face à l'informatisation: quelques projets et résultats. In J.-P. Chauveau, M. Barbato \& I. FernándezOrdóñez (éd.). Actes du XXVII Congrès international de linguistique et de philologie romanes (Nancy, 15-20 juillet 2013). Section 8: Linguistique variationnelle, dialectologie et sociolinguistique. Nancy: ATILF, pp. 193-207, http://www.atilf.fr/cilpr2013/actes/section-8/CILPR-2013-8Olariu-Olariu-Clim-Luca.pdf.

Olariu, Fl.-T., Olariu, V., Luca, R. (2016). Atlasul lingvistic audiovizual al Bucovinei (ALAB) - repere metodologice. In D. Loşonţi, V. Vlasin \& N. Mocanu (ed.). Lucrările celui de-al XVI-lea Simpozion international de dialectologie. Cluj-Napoca: Argonaut \& Scriptor, pp. 327-329.

Petraru, M.I. (1995-1996). Originea şi căile de imigrare ale polonezilor în Bucovina. In Suceava. Anuarul Muzeului Naţional al Bucovinei. XXII-XXIII, pp. 355-372.

Pintescu, Fl., Hrenciuc, D. (2002). Din istoria polonezilor in Bucovina. Suceava: Uniunea Polonezilor din Bucovina.

Robciuc, I. (1996). Raporturi lingvistice româno-ucrainene. I. Elemente româneşti în ucraineană. Bucureşti: Editura Mustang.

Stempel-Gancarczyk, K. (2016). Bucovina secolului al XX-lea - o Arcadie în amintirile membrilor comunităţii polonezilor din România (pe baza interviurilor şi a materialelor scrise din localităţile Bulai şi Vicşani). In Analele Bucovinei, XXIII/46, pp. 155-163.

Stempel-Gancarczyk, K. (2019). Dispariţia limbii în satele poloneze din Bucovina românească. In Analele Bucovinei. XXVI/52, pp. 241-245.

Stempel-Gancarczyk, K. (2020). Reflecţii asupra importanţei cercetărilor de teren în contextul analizei graiurilor poloneze pe cale de dispariţie din Bucovina românească. In Analele Bucovinei. XXVII/54 (în curs de apariţie). 